\title{
Spatial structure and movement of blue cod Parapercis colias in Doubtful Sound, New Zealand, inferred from $\delta^{13} \mathrm{C}$ and $\delta^{15} \mathrm{~N}$
}

\author{
Kirsten L. Rodgers, Stephen R. Wing* \\ Department of Marine Science, University of Otago, 310 Castle Street, Dunedin 9054, New Zealand
}

\begin{abstract}
Migrations and home range shifts by adult blue cod Parapercis colias provide an important means of dispersal among resident subpopulations within the Doubtful-Thompson Sound complex, a fjord system in southwestern New Zealand. In the present study we used stable isotope analysis $\left(\delta^{13} \mathrm{C}\right.$ and $\left.\delta^{15} \mathrm{~N}\right)$ to investigate regional differences in the carbon sources for, and likely migration patterns among, subpopulations of $P$. colias. We found consistent differences in $\delta^{13} \mathrm{C}$ and $\delta^{15} \mathrm{~N}$ of blood and muscle collected from outer coast (mean $\pm \mathrm{SE}$ : blood, $\delta^{13} \mathrm{C}=-18.4 \pm 0.2, \delta^{15} \mathrm{~N}=11.5 \pm 0.2$; muscle, $\delta^{13} \mathrm{C}=-17.9 \pm 0.1, \delta^{15} \mathrm{~N}=13.0 \pm 0.1$ ) and inner fjord (mean $\pm \mathrm{SE}$ : blood, $\delta^{13} \mathrm{C}=-19.9 \pm 0.5$, $\delta^{15} \mathrm{~N}=9.5 \pm 0.3 ;$ muscle, $\left.\delta^{13} \mathrm{C}=-19.3 \pm 0.4, \delta^{15} \mathrm{~N}=11.6 \pm 0.2\right)$ locations, likely reflecting long-term (>1 yr) residency. Inner fjord fish had evidence of significant input of recycled carbon from chemoautotrophic bacteria. On the outer coast, $\delta^{15} \mathrm{~N}$ and $\delta^{13} \mathrm{C}$ reflected a diet likely supported primarily by new production from macroalgae and phytoplankton. To provide information on isotopic turnover rate of blood and muscle we translocated fish from the outer coast to an inner fjord site and measured change in $\delta^{15} \mathrm{~N}$ and $\delta^{13} \mathrm{C}$ after $160 \mathrm{~d}$. These data showed a depletion of ${ }^{13} \mathrm{C}$ and ${ }^{15} \mathrm{~N}$ with shift in habitat and provided a basis for classifying likely migrants $(<160 \mathrm{~d})$ to each study site. The conclusion that populations of blue cod within Doubtful Sound are made up of long-term residents with some subsidy from the outer coast has implications for the efficacy of 2 newly established marine reserves in Doubtful Sound and others in Fiordland.
\end{abstract}

KEY WORDS: Stable isotopes $\cdot$ Metapopulation $\cdot$ Connectivity $\cdot$ Diet $\cdot$ Isotopic turnover $\cdot$ Temperate reef fish

Resale or republication not permitted without written consent of the publisher

\section{INTRODUCTION}

Information on metapopulation structure, in particular connectivity among local populations, remains a fundamental theme in marine population ecology (Kritzer \& Sale 2006) essential for understanding spatial population dynamics (Pulliam 1988, Hixon et al. 2002) and therefore the effectiveness of marine protected areas and other spatial management approaches (Quinn et al. 1993). Connectivity by exchange of larvae, recruits, or juveniles is an important mechanism for determining the spatial and demographic structure of coastal marine species (Roughgarden et al. 1985, Palumbi 2003). However, for some species movement of adults in the form of natal hom- ing, home range shifts or migrations may also substantially contribute to population connectivity (Thorrold et al. 2001). The relative rates and spatial scale of these exchanges among local subpopulations significantly influence rapid population replenishment and local buildup of reproductive potential and therefore have large implications for population dynamics and the efficacy of spatial management of marine species.

In some situations information on these types of migrations can be obtained from stable isotope signatures (Hobson 1999). The stable isotopic composition of a consumer provides an integrated reflection of the isotopic composition of its diet (DeNiro \& Epstein 1978, 1981, Tieszen et al. 1983) with a predictable amount of enrichment at each trophic level (Rau et al. 1983, 
McCutchan et al. 2003). If animals move between habitats with isotopically distinct prey communities, these signatures can be used to infer geographic origins, differentiate populations utilizing different habitats (Dufour et al. 1998, Melville \& Connolly 2003) and trace movement patterns (Fry 1981, 1983, 2006, Kurle \& Worthy 2002, Fry et al. 2003). The isotopic composition of a consumer will gradually change to reflect the new diet, thus serving as a natural marker for distinguishing recent immigrants from those that are equilibrated to the local isotopic signature (Fry 1983, Herzka 2005, Guelinckx et al. 2007). Accordingly, an understanding of the isotopic patterns in the environment is required to distinguish population structure and trace animal movement (Rubenstein \& Hobson 2004).

The present study used $\delta^{13} \mathrm{C}$ and $\delta^{15} \mathrm{~N}$ of blood and muscle tissue to investigate spatial structure of blue cod Parapercis colias populations in the DoubtfulThompson Sound complex, a fjord system on the southwest coast of New Zealand's South Island. P. colias are a conspicuous benthic predator in the rocky reef fish assemblage of southern New Zealand and support significant commercial and recreational fisheries around the South Island. Little is known about spawning behavior or early life history, including the distribution of juveniles. Growth rates can vary within and among areas, with a maximum age of 23 yr (S. R. Wing unpubl. data). Adults are typically relatively sedentary with restricted home ranges (Mace \& Johnson 1983, Cole et al. 2000). As a consequence $P$. colias are considered to be vulnerable to localized depletion because of a highly divided stock structure and moderate rates of movement among habitats (Carbines \& McKenzie 2004).

These concerns are particularly important in the 14 fjords that indent the southwest coast of the South Island, New Zealand, which present a highly fragmented and diverse array of habitats. The marine habitats in Fiordland also present a range of carbon sources with chemoautotrophic, terrestrial and freshwater primary producers particularly important in the inner fjord habitats (Lusseau \& Wing 2006, McLeod \& Wing 2007). In contrast, the outer regions of the fjords are exposed to the open ocean and have productive and diverse phytoplankton and macroalgal-based communities (Wing et al. 2007). The result is that food web structure and $\delta^{15} \mathrm{~N}$ and $\delta^{13} \mathrm{C}$ of primary producers in the inner fjords are distinct from that on the outer coast, indicating that migrants among habitats can be distinguished isotopically (Cornelisen et al. 2007, Wing et al. 2007).

One consequence of the fragmented habitat structure within Fiordland is that marine populations may be less well mixed and more likely to persist as popu- lation networks within fjords, with strong reproductive source-sink structures (S. R. Wing et al. 2003). The isolated basins of the inner fjords and predominant estuarine circulation play an important role in limiting larval dispersal and gene flow among fjords for marine organisms with a larval dispersal phase. Evidence for this comes from several sources including genetic studies of the eleven-armed sea star Coscinasterias muricata (Sköld et al. 2003, Perrin et al. 2004), the sea urchin Evechinus chloroticus (Perrin et al. 2003), and brachiopods Liothyrella neozelanica and Terebratella sanguinea (Ostrow et al. 2001).

We characterized spatial variability in the composition of diet and resulting $\delta^{13} \mathrm{C}$ and $\delta^{15} \mathrm{~N}$ of blood and muscle in blue cod Parapercis colias collected from different regions of the Doubtful-Thompson Sound complex. We then compared site-specific $\delta^{13} \mathrm{C}$ and $\delta^{15} \mathrm{~N}$ of $P$. colias with the primary carbon source pools (macroalgae, phytoplankton and chemoautotrophic endosymbionts). To simulate migration we investigated isotopic turnover in blood and muscle tissue in situ by relocating individuals from the outer to inner region of Doubtful Sound and quantifying turnover in $\delta^{13} \mathrm{C}$ and $\delta^{15} \mathrm{~N}$ between time of relocation and recapture. Stomach contents (immediate past) as well as $\delta^{13} \mathrm{C}$ and $\delta^{15} \mathrm{~N}$ of blood (recent past) and muscle (long-term past) provided an indication of individual dietary history integrated over a range of timescales (Tieszen et al. 1983). The measure of turnover in these tissues was then used as a basis for identifying migrants between the outer coast and inner fjord habitats. These data provided valuable insight into the pattern of movement and home range shifts for $P$. colias within the fjord, which are discussed in the context of their implications for source-sink structure and population replenishment within 2 recently established marine reserves in the region.

\section{MATERIALS AND METHODS}

Sample collection. Adult blue cod were sampled from 2 inner fjord $(n=35)$ and 2 outer coast $(n=34)$ locations in the Doubtful-Thompson Sound complex $\left(45^{\circ} 30^{\prime} \mathrm{S}, 167^{\circ} 0^{\prime} \mathrm{E}\right)$ between May 2004 and January 2005 (Fig. 1), chosen to represent distinct regions in the isotopic signatures of primary producers present in the fjord (Cornelisen et al. 2007). Fish were immediately frozen and later thawed at Portobello Marine Laboratory (PML), where samples of blood and muscle tissue were collected. Stomachs were removed and preserved in $70 \%$ isopropyl alcohol (IPA).

Sample preparation for stable isotope analysis (SIA). Blood and muscle tissue samples were dried at $60^{\circ} \mathrm{C}$ for $2 \mathrm{~d}$ and ground to a fine powder by mortar and 


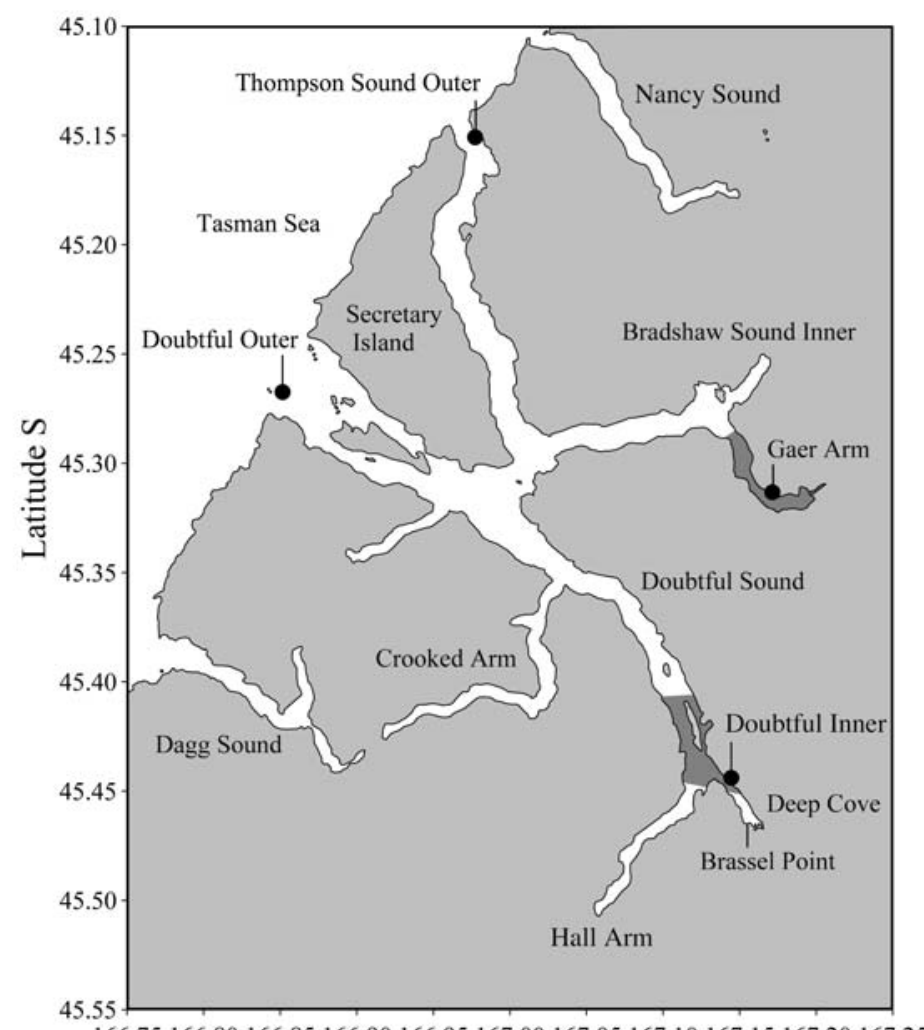

166.75166 .80166 .85166 .90166 .95167 .00167 .05167 .10167 .15167 .20167 .25 Longitude E

Fig. 1. Doubtful-Thompson Sound complex with sampling stations ( ) and the release point of translocated fish (Brassel Point). Shaded regions indicate the marine reserves at Gaer Arm (Kutu Parera) and Elizabeth Island (Taipari Roa)

pestle. Lipids were extracted from an additional muscle sample taken from a random sub-sample of 10 fish from inner $(n=5)$ and outer $(n=5)$ fjord sites. The lipid fraction was extracted with a chloroform methanol (2:1) solution following (Bligh \& Dyer 1959). Lipidextracted and unaltered muscle samples were then prepared for SIA. For each sample $1.0 \mathrm{mg}$ of ground tissue was sealed into a tin capsule and analyzed for $\delta^{13} \mathrm{C}$ and $\delta^{15} \mathrm{~N}$ at Iso-Trace NZ on a Europa 20-20 update stable isotope mass spectrometer (MS) interfaced to a Carlo Erba elemental analyzer (NA1500) in continuous flow mode (precision: $0.2 \%$ ). Analysis was calibrated to ethylene diamine tetraacetic acid (EDTA) laboratory standard reference (Elemental Microanalysis) and standardized against international standards (IAEACH-6 for carbon, IAEAN1 and IAEAN2 for nitrogen). Results are expressed in standard delta notation (e.g. Peterson 1999).

Statistical analysis of $\delta^{13} \mathbf{C}$ and $\delta^{15} \mathrm{~N}$. The relationship between fish length and stable isotope signature was analyzed using linear regressions for $\delta^{13} \mathrm{C}$ and $\delta^{15} \mathrm{~N}$ separately. One-way analysis of variance (ANOVA) was used to compare $\delta^{13} \mathrm{C}$ and $\delta^{15} \mathrm{~N}$ between blood and muscle tissue and among regions for each tissue. Oneway ANOVA was used to compare $\delta^{13} \mathrm{C}$ and $\delta^{15} \mathrm{~N}$ among sites, with a Tukey honestly significant difference (HSD) post-hoc test used to resolve pairwise differences. For analysis at the regional level, in absence of significant differences at the site level, samples from the 2 outer fjord sites and those from the 2 inner fjord sites were pooled.

Stomach content analysis. Stomach contents were sorted and classified into 8 broad taxonomic categories: algae, thaliacea, crustacea, mollusca, polychaeta, echinodermata, fish, Solemya parkinsoni and other unidentified prey items. $S$. parkinsoni is a chemoautotrophic clam that has a distinctively depleted isotopic signature (mean $\pm \mathrm{SE}: \delta^{15} \mathrm{~N}=-5.5 \pm 0.5$; $\delta^{13} \mathrm{C}=-31.3 \pm 0.1$ ) that may have a significant effect on the $\delta^{13} \mathrm{C}$ signature of animals that feed on it; therefore, it was shown as a separate category. Stomachs were classified as empty if there were no prey items in the entire visceral canal. The difference in the proportion of empty stomachs among sites was tested with a Pearson chi-square test. To account for differences in fish size, stomach content weight data was expressed as a percentage of total wet body weight (\% BW). Only 2 fish were obtained from outer Thompson Sound and isotopic signatures showed no significant difference from those collected from outer Doubtful Sound, so for the purposes of diet analysis the 2 sites were pooled. Diet composition at the 3 sites based on these categories was compared based on the average weight of each category in proportion to the total stomach content weight $(\% \mathrm{BW})$. The effect of the presence or absence of $S$. parkinsoni on the $\delta^{13} \mathrm{C}$ signature of blood and muscle was tested by 1-way ANOVA.

Field relocation experiment. Forty-six adult blue cod were captured from the outer Doubtful Sound region over 2 wk (24 to 28 May and 21 to 25 June 2004) using large baited hooks (Carbines 1999). Each fish was anaesthetized in a bath of MS-222, weighed, measured (total length) and $0.25 \mathrm{ml}$ of blood was extracted from the dorsal vein with a 21 gauge $1 \frac{1}{2}$ TW needle. Fish were tagged at the base of the pelvic fin with an individually numbered Hall Print plastic dart tag before being transported $33.4 \mathrm{~km}$ and released at Brassel Point in Deep Cove, Doubtful Sound (45⒉751' S, $167^{\circ} 09.482^{\prime} \mathrm{E}$ ) (Fig. 1). Blood samples were stored at $-60^{\circ} \mathrm{C}$ at PML. Two $1 \mathrm{wk}$ targeted recapture phases using baited fish traps (steel rod measuring $106 \times 106 \times$ $53 \mathrm{~cm}$ with mesh size $3 \times 2.5$ and two $29 \mathrm{~cm}$ diameter openings) were undertaken in November 2004 and January 2005. In addition, the public were notified of the project and asked to return any tagged blue cod. Three traps were simultaneously deployed at depths ranging from 8 to $25 \mathrm{~m}$ and left for 7 to $24 \mathrm{~h}$ (mean $13.8 \mathrm{~h}$ ). Initial trap sets were concentrated around the 
release point at Brassel Point and then spread out around Deep Cove at least $50 \mathrm{~m}$ apart. Blood samples, weight and length were immediately collected from recaptured fish. A sample of blood and dorsal muscle was taken from each recaptured blue cod, which along with the initial blood sample was dried at $60^{\circ} \mathrm{C}$ for $2 \mathrm{~d}$ and prepared for SIA.

To provide an independent test of tag retention 25 blue cod were tagged at PML and held in large outdoor tanks for $225 \mathrm{~d}$, over which period 3 fish lost their tags $(12 \%$ tag loss). No mortalities over this time were attributed to the presence of the tag, consistent with results of Carbines \& McKenzie (2004).

Daily rate of change of $\delta^{13} \mathrm{C}$ and $\delta^{15} \mathrm{~N}$ was calculated for each recaptured fish and normalized to the average time at large $(160 \mathrm{~d})$. The change in $\delta^{13} \mathrm{C}$ and $\delta^{15} \mathrm{~N}$ between tag and recapture were compared by ANOVA. We tested for differences between initial $\delta^{13} \mathrm{C}$ and $\delta^{15} \mathrm{~N}$ of blood and the average $\delta^{13} \mathrm{C}$ and $\delta^{15} \mathrm{~N}$ of blood from outer and inner regions, as well as between $\delta^{13} \mathrm{C}$ and $\delta^{15} \mathrm{~N}$ of blood and muscle at recapture with $\delta^{13} \mathrm{C}$ and $\delta^{15} \mathrm{~N}$ of both tissues from outer and inner regions. Growth rate in length for the time interval between tag and recapture was analyzed by 1-way ANOVA.

Estimate of migrants. The fraction of likely migrants for the inner fjord populations and long-term residents for the outer coastal population was estimated by calculating the divergence (depletion in ${ }^{13} \mathrm{C}$ and ${ }^{15} \mathrm{~N}$ ) of $\delta^{13} \mathrm{C}$ and $\delta{ }^{15} \mathrm{~N}$ in blood from the average $\delta^{13} \mathrm{C}$ and $\delta^{15} \mathrm{~N}$ of blood from fish collected at the outer coastal site. In this analysis we used the average divergence of $\delta{ }^{13} \mathrm{C}$ and $\delta^{15} \mathrm{~N}$ in blood observed in $160 \mathrm{~d}$ from the transplant experiment to define likely migrants from longerterm residents. For the inner fjord populations individuals with $\delta^{13} \mathrm{C}$ and $\delta^{15} \mathrm{~N}$ of blood that had not diverged more than observed in $160 \mathrm{~d}$ during the transplant experiment were classed as migrants for the inner fjord population and residents for the outer coastal popula- tion. Standard error of these estimates was calculated from the standard error of the observed divergence.

\section{RESULTS}

\section{Spatial patterns in $\delta^{13} \mathrm{C}$ and $\delta^{15} \mathrm{~N}$}

The results of $\delta^{13} \mathrm{C}$ and $\delta^{15} \mathrm{~N}$ analyses of blood and muscle tissue are summarized in Table 1 . There was no relationship between fish length and $\delta^{13} \mathrm{C}$ of blood $\left(r^{2}=0.0514\right)$ or muscle $\left(r^{2}=0.0318\right)$ or $\delta^{15} \mathrm{~N}$ of blood $\left(\mathrm{r}^{2}=0.0016\right)$ or muscle $\left(\mathrm{r}^{2}=0.0029\right)$. Across all samples $\delta^{15} \mathrm{~N}$ was significantly different between blood and muscle $\left(\mathrm{p}<0.0001, F_{1,137}=45.49, \mathrm{n}=138\right)$, but $\delta^{13} \mathrm{C}$ was not significantly different between the 2 tissues $\left(\mathrm{p}=0.128, F_{1,137}=2.34, \mathrm{n}=138\right)$. There were significant differences in $\delta^{15} \mathrm{~N}$ between tissue types in both inner $\left(\mathrm{p}<0.0001, F_{1,69}=27.82, \mathrm{n}=70\right)$ and outer regions ( $\left.p<0.0001, F_{1,67}=73.85, \mathrm{n}=68\right)$. The outer region also showed significant differences in $\delta^{13} \mathrm{C}$ between tissues $\left(\mathrm{p}=0.017, F_{1,67}=5.99, \mathrm{n}=68\right)$, but the inner region did not $\left(\mathrm{p}=0.335, F_{1,69}=0.94, \mathrm{n}=70\right)$. Lipid content did not have a significant effect on $\delta^{13} \mathrm{C}$ of muscle tissue $\left(\mathrm{p}=0.495, F_{1,10}=4.41, \mathrm{n}=11\right)$, indicating that it is not necessary to remove lipids before SIA in this case. The average $\delta^{15} \mathrm{~N}$ and $\delta^{13} \mathrm{C}$ of blood was more depleted than the average $\delta^{15} \mathrm{~N}$ and $\delta^{13} \mathrm{C}$ of muscle, confirming the need to separately analyze the 2 tissues for analysis of spatial and temporal patterns.

Blue cod from the inner region of the fjord were significantly more depleted in $\delta^{15} \mathrm{~N}$ and $\delta^{13} \mathrm{C}$ than those from the outer region in both blood $\left(\delta^{15} \mathrm{~N}, \mathrm{p}<0.0001\right.$, $F_{1,68}=33.01, \mathrm{n}=69 ; \delta^{13} \mathrm{C}, \mathrm{p}=0.007, F_{1,68}=7.65, \mathrm{n}=69$ ) and muscle $\left(\delta^{15} \mathrm{~N}, \mathrm{p}<0.0001, F_{1,69}=27.99, \mathrm{n}=70 ; \delta^{13} \mathrm{C}\right.$, $\mathrm{p}=0.001, F_{1,69}=12.38, \mathrm{n}=70$ ) (Table 1). There was larger variation in $\delta^{13} \mathrm{C}$ and $\delta^{15} \mathrm{~N}$ among blue cod in the inner region than those in the outer region of the fjord in both blood (Fig. 2a) and muscle (Fig. 2b).

Table 1. Parapercis colias. Summary of $\delta^{15} \mathrm{~N}$ and $\delta^{13} \mathrm{C}$ in blood and muscle tissue

\begin{tabular}{|c|c|c|c|c|c|}
\hline $\begin{array}{l}\text { Site } \\
\text { Region }\end{array}$ & $\mathrm{N}$ & $\begin{array}{c}\delta^{13} \mathrm{C} \\
\text { Mean (range) } \\
\text { (SE) }\end{array}$ & $\begin{array}{c}\delta^{15} \mathrm{~N} \\
\text { Mean (range) } \\
\text { (SE) }\end{array}$ & $\begin{array}{c}\delta^{13} \mathrm{C} \\
\text { Mean (range) } \\
(\mathrm{SE})\end{array}$ & $\begin{array}{c}\delta^{15} \mathrm{~N} \\
\text { Mean (range) } \\
\text { (SE) }\end{array}$ \\
\hline $\begin{array}{l}\text { Doubtful } \\
\text { Outer }\end{array}$ & 32 & $\begin{array}{c}-18.4(-20.7,-16.8) \\
(0.17)\end{array}$ & $\begin{array}{c}11.6(9.8,13.4) \\
(0.16)\end{array}$ & $\begin{array}{c}-17.9(-18.9,-16.6) \\
(0.12)\end{array}$ & $\begin{array}{c}13.0(12.0,13.8) \\
(0.07)\end{array}$ \\
\hline $\begin{array}{l}\text { Thompson } \\
\text { Outer }\end{array}$ & 2 & $\begin{array}{c}-18.7(-18.9,-18.5) \\
(0.17)\end{array}$ & $\begin{array}{c}10.8(10.6,11.0) \\
(0.19)\end{array}$ & $\begin{array}{c}-18.3(-18.6,-18.0) \\
(0.33)\end{array}$ & $\begin{array}{c}12.9(12.8,13.0) \\
(0.13)\end{array}$ \\
\hline $\begin{array}{l}\text { Doubtful } \\
\text { Inner }\end{array}$ & 24 & $\begin{array}{c}-18.8(-23.1,-15.9) \\
(0.42)\end{array}$ & $\begin{array}{c}9.9(6.3,13.1) \\
(0.37)\end{array}$ & $\begin{array}{c}-19.3(-25.7,-17.0) \\
(0.48)\end{array}$ & $\begin{array}{c}12.0(9.9,14.7) \\
(0.23)\end{array}$ \\
\hline $\begin{array}{l}\text { Bradshaw } \\
\text { Inner }\end{array}$ & 11 & $\begin{array}{c}-22.5(-29.5,-16.7) \\
(1.03)\end{array}$ & $\begin{array}{c}8.7(5.3,11.0) \\
(0.50)\end{array}$ & $\begin{array}{c}-19.4(-24.0,-16.7) \\
(0.59)\end{array}$ & $\begin{array}{c}10.8(7.5,13.3) \\
(0.53)\end{array}$ \\
\hline
\end{tabular}




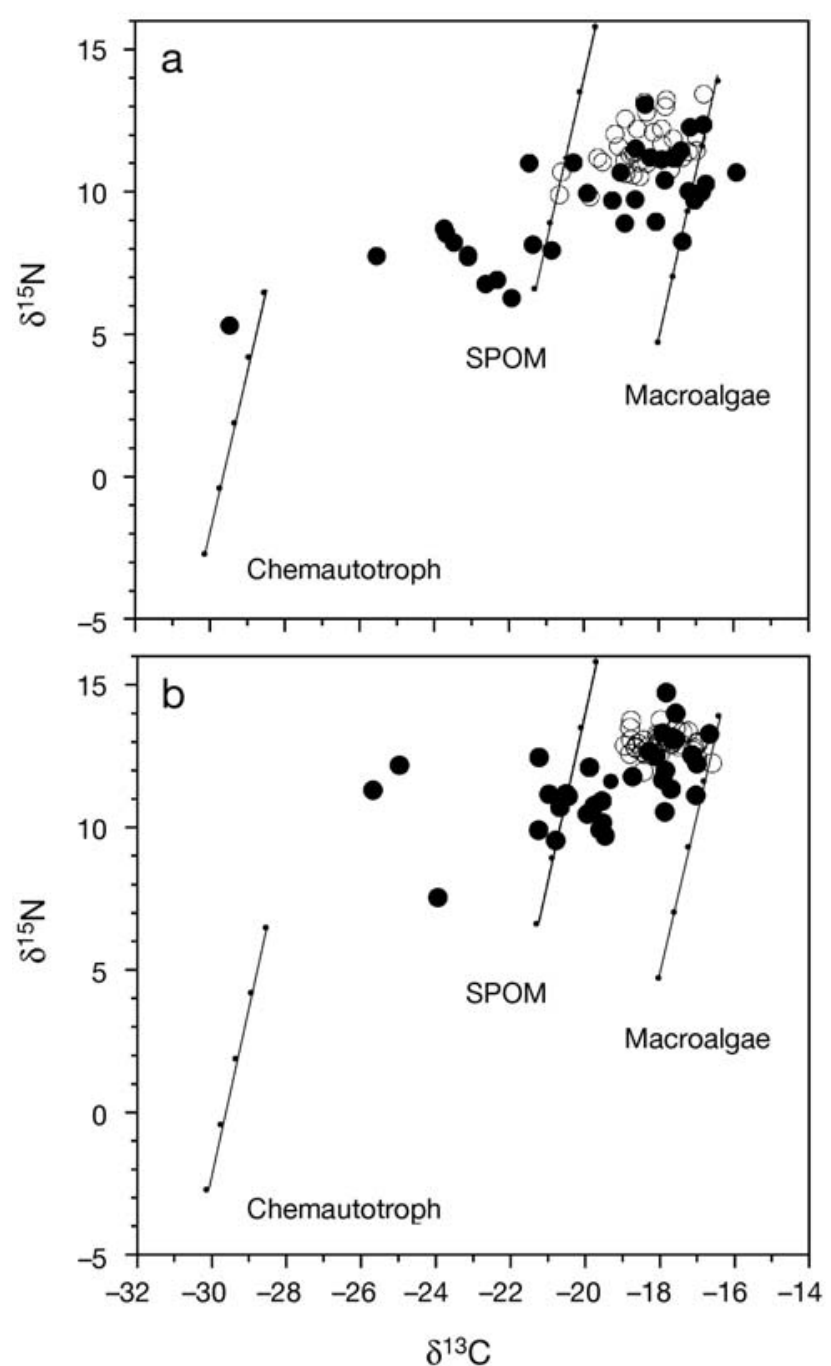

Fig. 2. Parapercis colias. $\delta^{13} \mathrm{C}$ and $\delta^{15} \mathrm{~N}$ of (a) blood and (b) muscle tissue from blue cod collected from outer coast sites (O) $(\mathrm{n}=34)$ and for those collected from inner fjord sites $(\bullet)$ $(\mathrm{n}=35)$. Carbon sources, chemoautotrophs, suspended particulate organic matter (SPOM) and macroalgae indicated by

lines of trophic enrichment from Lusseau \& Wing (2006)

\section{Diet analysis}

The proportion of empty stomachs ranged from 14 to $21 \%$ and was not significantly different among sites $\left(\mathrm{r}^{2}=\right.$ $0.440, \mathrm{df}=2, \mathrm{p}=0.80, \mathrm{n}=70$ ). The composition of diet based on the 8 taxonomic categories varied among sites (Fig. 3). Diet in the inner and outer regions of Doubtful Sound was composed of a greater number of prey categories compared to the diet in inner Bradshaw Sound. In outer Doubtful Sound the diet consisted mostly of molluscs $(20 \%)$ and fish (18\%) and was the only site where thaliaceans (salps) were present in the diet. Small benthic fish (39\%) played an important part in the diet in inner Doubtful Sound, followed by Solemya parkinsoni a

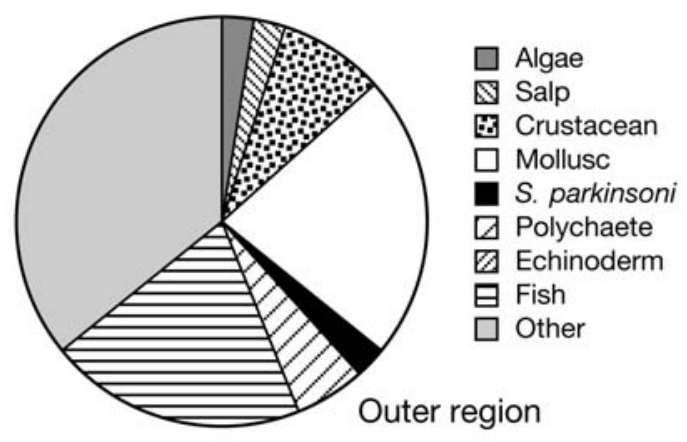

b

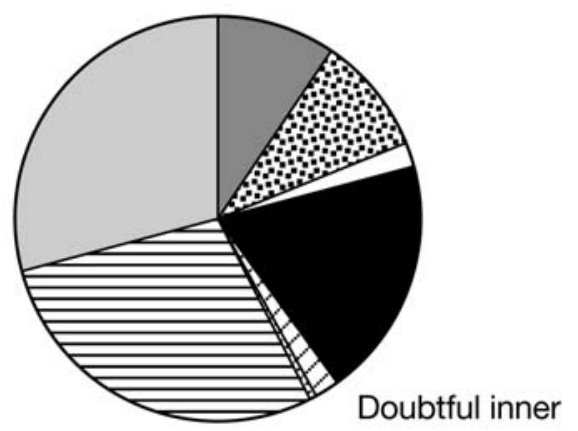

C

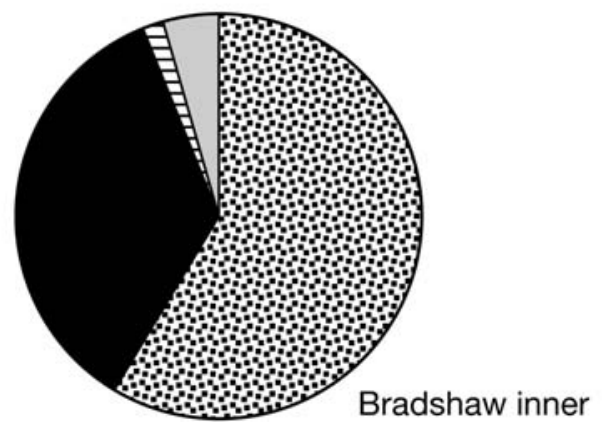

Fig. 3. Composition of diet as average fraction of body weight among 9 taxonomic categories from (a) outer coast $(\mathrm{n}=34$ ), (b) Doubtful Sound inner $(\mathrm{n}=24)$ and $(\mathrm{c})$ Bradshaw Sound inner sites $(\mathrm{n}=11)$. Note the large contribution of Solemya parkinsoni at the inner fjord sites

(26\%). In Bradshaw Sound the diet was dominated by crustaceans (47\%) and S. parkinsoni $(28 \%)$. S. parkinsoni was present in the stomachs of $5.7 \%$ of blue cod from the outer site, compared to $15.4 \%$ from Doubtful inner and $27.3 \%$ from Bradshaw (Gaer Arm). A total of 9 fish were found with $S$. parkinsoni in their stomachs, and of those, 6 contained exclusively $S$. parkinsoni. The presence of $S$. parkinsoni in the stomach contents corresponded to $\delta^{13} \mathrm{C}$ of blood significantly more depleted in ${ }^{13} \mathrm{C}$ compared to samples where it was absent in both outer $\left(\mathrm{p}=0.003, F_{1,33}=10.13, \mathrm{n}=34\right)$ and inner regions $\left(\mathrm{p}=0.015, F_{1,34}=6.66, \mathrm{n}=35\right)($ Fig. 4$)$ but did not have a significant effect on the $\delta^{13} \mathrm{C}$ signatures in muscle in either outer $\left(\mathrm{p}=0.109, F_{1,33}=2.71, \mathrm{n}=34\right)$ or inner regions $\left(\mathrm{p}=0.36, F_{1,34}=0.84, \mathrm{n}=35\right)$. 


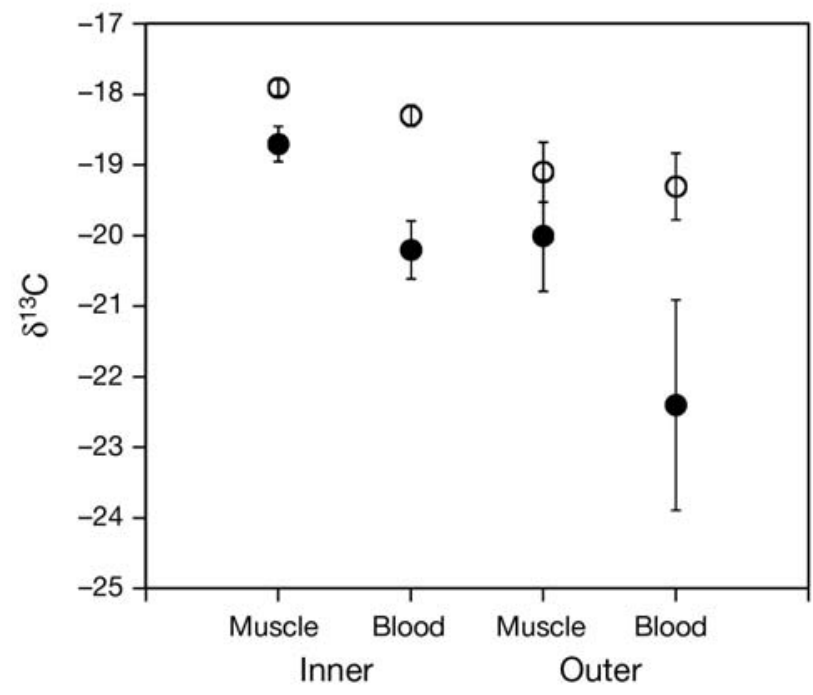

Fig. 4. Parapercis colias. $\delta^{13} \mathrm{C}$ of blood and muscle tissue from blue cod collected from inner fjord $(n=35)$ and outer coast $(\mathrm{n}=34)$ sites with Solemya parkinsoni present $(\bullet)$ or absent (O) in their stomach contents. Error bars are $\pm 1 \mathrm{SE}$

\section{Translocation experiment}

Six translocated blue cod were recaptured (4 returned by the public, 2 in traps during recapture phase) in Deep Cove over the following 6 mo, a recapture rate of $13 \%$. Growth in length between translocation and recapture was not significant $(\mathrm{p}=0.610$, $F_{1,5}=0.27, \mathrm{n}=6$ ). One translocated blue cod was recaptured by the public after $15 \mathrm{~d}$ at liberty and showed no difference in $\delta^{13} \mathrm{C}$ but was $0.4 \%$ more depleted in $\delta{ }^{15} \mathrm{~N}$ on recapture. This individual was excluded from further analysis because of the short time at liberty in Deep Cove. The 5 other recaptured fish showed a consistent pattern in depletion of $\delta^{15} \mathrm{~N}$ and $\delta^{13} \mathrm{C}$ for blood compared to the signatures measured before translocation. The average rate of $\delta^{13} \mathrm{C}$ change was $0.0076 \% \mathrm{~d}^{-1}$ (ranging from 0.0018 to $0.0197 \%$ ) and $0.0044 \% \mathrm{~d}^{-1}$ for $\delta^{15} \mathrm{~N}$ (ranging from 0 to $0.0071 \%$ ).

Prior to translocation the $\delta^{13} \mathrm{C}$ of blood for the 5 fish were within a $1 \%$ range and $\delta^{15} \mathrm{~N}$ was within a $1.5 \%$ range. On recapture there was up to $2.1 \%$ variation in $\delta^{13} \mathrm{C}$ among the 5 individuals but less variability in $\delta^{15} \mathrm{~N}$ (maximum $0.7 \%$ ). The initial isotopic signatures of blood of the tagged fish were not different from those of blue cod in the outer region of Doubtful Sound. Although there was considerable individual variability, $\delta^{13} \mathrm{C}$ and $\delta^{15} \mathrm{~N}$ of blood for the 5 translocated fish at recapture had shifted to become intermediate between those from the outer and inner Doubtful regions. $\delta^{13} \mathrm{C}$ of blood of all recaptured fish normalized to $160 \mathrm{~d}$ were not significantly different from pre-translocation val- ues ( $\left.\mathrm{p}=0.067, F_{1,4}=4.48, \mathrm{n}=5\right)$, but $\delta^{15} \mathrm{~N}$ became significantly more depleted in ${ }^{15} \mathrm{~N}\left(\mathrm{p}=0.024, F_{1,4}=7.71\right.$, $\mathrm{n}=5$ ). Although not significant, a clear trend to $\delta^{13} \mathrm{C}$ more depleted in ${ }^{13} \mathrm{C}$ was evident.

\section{Estimate of migrants}

Results from the analysis of likely migrants, estimated from divergence of $\delta^{13} \mathrm{C}$ and $\delta^{15} \mathrm{~N}$ in blood from those of fish collected at the outer coast site, indicated that the proportion $( \pm \mathrm{SE})$ of likely migrants at Deep Cove was $0.54 \pm 0.13$, at Gaer Arm (Bradshaw Sound) $0.27 \pm 0.014$ and for the outer region $0.17 \pm 0.029$.

\section{DISCUSSION}

The results of the present study add support to the idea that Parapercis colias populations are spatially structured across different habitats in the DoubtfulThompson Sound complex and contribute to the growing body of evidence that adult blue cod form resident subpopulations on the scale of tens of kilometers in enclosed waterways due to limited migration and restricted home ranges on the temporal scale of $1 \mathrm{yr}$ (Cole et al. 2000, Carbines \& McKenzie 2004, Beentjes $\&$ Carbines 2005). The observed spatial differences in $\delta^{13} \mathrm{C}$ and $\delta^{15} \mathrm{~N}$ of blood and muscle tissue from blue cod collected at inner and outer regions of the DoubtfulThompson Sound complex are likely a result of limited mixing (17 to $54 \%$ ) of adults among these subpopulations on the timescale of $1 \mathrm{yr}$. If the adult fish were completely mixing among locations on this time scale, then isotopic signatures among individuals over the entire fjord would be more similar, based on isotopic turnover rates of blood and muscle tissue for the species observed in situ.

Estimates indicate that the population in inner Doubtful Sound had a larger fraction of likely migrants (54\%) than the population at Gaer Arm (Bradshaw Sound) $(27 \%)$ followed by the population from the outer coast region $(17 \%)$. These patterns among the 2 inner fjord populations likely reflect differences in fishing mortality and migration rate, though several alternative hypotheses must be considered.

The use of stable isotopes as a tool for analyzing population structure and movement requires spatial variation in isotopic signatures among potential diets, often associated with different habitats. In the New Zealand fjords this is provided by differences in community structure, isotopic variance within primary producers and relative importance of carbon source pools to food webs in inner and outer regions of the fjords (Cornelisen et al. 2007, McLeod \& Wing 2007, 
Wing et al. 2007). High annual rainfall (>7000 mm $\mathrm{yr}^{-1}$ ) and freshwater input from the Manapouri hydroelectric plant (350 to $510 \mathrm{~m}^{3} \mathrm{~s}^{-1}$ ) result in a welldefined surface low salinity layer (LSL) that has been shown to play a major role in controlling intertidal and subtidal community structure (Witman \& Grange 1998, Boyle et al. 2001, Rutger \& Wing 2006). The tannin-stained LSL in the inner fjord regions creates a low-light environment, which coupled with low tidal- and wave-induced current flow, inhibits the growth of kelp (Miller et al. 2006, Wing et al. 2007). Benthic production within the fjords is therefore relatively limited, and the production that occurs in the estuarine algal community within the LSL likely accounts for a large component of the benthic primary production in the inner fjord (Wing et al. 2001, Clark 2005, Cornelisen et al. 2007). Pelagic production is dominated by seasonal phytoplankton blooms that are initiated by vertical mixing during episodic high freshwater influx in Doubtful Sound (Goebel et al. 2005). The limited algal and phytoplankton-based inputs into the inner fjord system, and the predominance of terrestrial detritus inputs and recycling of carbon via chemoautotrophic bacteria, lead to an inner fjord food web generally depleted in ${ }^{13} \mathrm{C}$ and ${ }^{15} \mathrm{~N}$ compared to the outer coast food web (McLeod \& Wing 2007).

The type of tissue analyzed directly influences studies of diet, trophic relationships and habitat shifts because of isotopic variation among different tissues and different turnover rates. This results in variance in the time to equilibrate with the isotopic composition of the present diet. More metabolically active tissues such as liver, pancreas and blood have faster turnover rates than less active tissues such as bone, muscle, feathers and hair (DeNiro \& Epstein 1978, Tieszen et al. 1983). Analysis of multiple tissues from a single animal therefore allows a more complete estimate of the isotopic composition of the diet and feeding location over a range of timescales (Tieszen et al. 1983, Kurle \& Worthy 2002).

Samples of blood and muscle from blue cod from the outer region were more enriched in ${ }^{15} \mathrm{~N}$ and ${ }^{13} \mathrm{C}$ compared to those from both inner fjord regions. $\delta^{15} \mathrm{~N}$ and $\delta^{13} \mathrm{C}$ of muscle was less variable than $\delta^{15} \mathrm{~N}$ and $\delta^{13} \mathrm{C}$ of blood among fish within sites reflecting the longer-term dietary integration of this tissue. This pattern suggests that fish from the inner fjords have a significant input of recycled carbon from Solemya parkinsoni, which hosts chemoautotrophic bacteria, but is likely to include other chemoautotrophic species (Lusseau \& Wing 2006, McLeod \& Wing 2007). This conclusion is reinforced by the dietary analysis demonstrating the link between $S$. parkinsoni in the diet and isotopic signatures of blood and muscle. In contrast, the values of $\delta^{15} \mathrm{~N}$ and $\delta^{13} \mathrm{C}$ enriched in ${ }^{13} \mathrm{C}$ and ${ }^{15} \mathrm{~N}$ among the outer coast population is consistent with a long-term diet supported by new production, primarily macroalgae and phytoplankton. Stomach content analysis was a useful complementary technique to assist in the interpretation of these patterns in $\delta^{15} \mathrm{~N}$ and $\delta^{13} \mathrm{C}$ and demonstrated the consistent general use of chemoautotrophs in the inner fjord blue cod populations.

Although $\delta^{15} \mathrm{~N}$ and $\delta^{13} \mathrm{C}$ in blue cod were significantly different between inner and outer regions of Doubtful Sound, there were some individuals with intermediate $\delta^{13} \mathrm{C}$ and $\delta^{15} \mathrm{~N}$ for blood that overlapped between the 2 groups. There are several alternative hypotheses to explain these overlapping signatures and the differentiation of isotopic signatures among areas. The first hypothesis is that these fish obtained isotopically different signatures from their diets within each region independently. For example, there could have been some specialization of diet by individual fish that preyed on Solemya parkinsoni or other invertebrates with chemoautotrophic symbionts. The second hypothesis is that fish with intermediate signatures represent animals that had moved and still retained average isotopic information from their previous habitat. That is, the individuals with intermediate signatures captured in the inner fjords may represent the transient proportion of the population that has moved from outer coast to inner fjord habitats. A third hypothesis explaining isotopic disequilibrium is dietary change related to ontogenetic shifts (Fry 1983). However, this explanation was discounted in the present study because all fish sampled were adult individuals, and there was no significant trend in isotopic signature with fish length. One additional hypothesis to explain the observed variability in $\delta^{13} \mathrm{C}$ and $\delta^{15} \mathrm{~N}$ among sites is the influence of fat content on bulk tissue isotopic signatures. Tissues that have a high lipid component tend to be significantly more depleted in ${ }^{13} \mathrm{C}$ compared to those with lower lipid content (DeNiro \& Epstein 1978, Tieszen et al. 1983, Pinnegar \& Polunin 1999). This was not considered an important issue in the present study because there were no significant differences in $\delta^{13} \mathrm{C}$ between lipid-extracted and nonextracted muscle tissue.

The translocation experiment provided support for the second hypothesis as the most parsimonious by demonstrating the pattern of isotopic change that occurs when fish 'migrate' or, in this case, are moved from the outer to inner region of the fjord. All recaptured fish in this experiment demonstrated a consistent pattern of change toward values of $\delta^{13} \mathrm{C}$ and $\delta^{15} \mathrm{~N}$ more depleted in ${ }^{13} \mathrm{C}$ and ${ }^{15} \mathrm{~N}$. This pattern corroborates the observed spatial patterns in natural abundance of $\delta^{15} \mathrm{~N}$ and $\delta^{13} \mathrm{C}$ and is consistent with change 
expected with movement from the outer coast food web, based on phytoplankton and macroalgae primary production, to the inner fjord food web, where estuarine, terrestrial and recycled production are important contributors (McLeod \& Wing 2007). This supposition was reinforced by the dietary analysis that indicated a large proportion of the average diet at the 2 inner fjord sites was made up of the chemoautotrophic clam Solemya parkinsoni with no apparent specialization among individuals. This pattern is consistent with dietary studies of Parapercis colias, where specialization has not been observed, but rather fish prey on a wide variety of invertebrates and fish available in different benthic habitats (Jiang \& Carbines 2002). Nevertheless, we cannot fully discount specialization as an explanation for the observed isotopic variability since it was not explicitly measured in the present study. Use of trace elemental markers in the otoliths of these fish (Thorrold et al. 2001) would provide a measure that is independent of diet and a clear method to differentiate movement from dietary specialization in this system.

In $184 \mathrm{~d} \delta^{15} \mathrm{~N}$ and $\delta^{13} \mathrm{C}$ of blood tissue from relocated individuals had not reached equilibrium with the average $\delta^{15} \mathrm{~N}$ and $\delta^{13} \mathrm{C}$ of fish from the inner fjord. This result suggests that, if the second hypothesis is true, movements from the outer coast, or other areas with isotopically enriched available diets, produce intermediate isotopic signatures in blood tissue. Accordingly, it would be possible to identify a migrant wild fish for longer than $184 \mathrm{~d}$ after a home range shift to the inner fjord. Estimation of the proportion of the outer coast and inner fjord populations that were likely migrants was achieved by an analysis of the divergence of the isotopic signature in blood of individuals, based on the average divergence of $\delta^{13} \mathrm{C}$ and $\delta^{15} \mathrm{~N}$ in transplanted fish after $160 \mathrm{~d}$ from the average local population signature.

The present experiment was the first time adult reef fish have been relocated between regions with isotopically distinct food sources to investigate isotopic turnover in situ. The relatively enclosed physical structure of Deep Cove at the head of a fjord increased the chance of recapturing relocated fish. The observed isotopic change in blood tissues of blue cod within $184 \mathrm{~d}$ departs from the suggestion by Hansson et al. (1997) and Herzka (2005) that slow-growing adult fish may maintain the isotopic composition of their previous habitat indefinitely if movement occurs in the latter part of the lifecycle.

The relocation experiment also provided the basis for identifying possible migrants within the adult fish at the 2 inner fjord regions (Deep Cove and Gaer Arm). These estimates indicate that the fraction of the population made up of likely migrants in Deep Cove is greater than that in Gaer Arm. This pattern may reflect the higher fishing pressure associated with the landing and access point at Deep Cove (e.g. Lusseau \& Wing 2006), leading to a greater turnover of adults in the inner fjord. Alternatively, the pattern is consistent with differences in migration rate, local productivity, or differences in the topographic isolation of the 2 inner fjord habitats, although both regions are similar distances from the outer coast.

Spatial patterns in $\delta^{15} \mathrm{~N}$ and $\delta^{13} \mathrm{C}$ resolved in the present study support the idea that blue cod in the Doubtful-Thompson Sound complex form resident subpopulations on a scale of tens of kilometers and temporal scale of $1 \mathrm{yr}$, but does not imply reproductive isolation or restricted gene flow. This type of adult dispersal pattern was also observed in a tagging study carried out in Dusky Sound, Fiordland, where $65 \%$ of all recaptures after 1 yr occurred within $1 \mathrm{~km}$ of their release site (Carbines \& McKenzie 2004). Moderate levels of adult movement among regions of the fjord and the possibility that a large component of movement is from the outer to inner fjord region has implications for the stability and resilience of coastal populations (Orensanz \& Jamieson 1998) and efficacy of spatial management, including the 8 newly established marine reserves in Fiordland.

The results of the present study indicate that home range shifts likely provide an important mechanism for subsidizing recruitment to local coastal populations. Information about spatial structure, scale and direction of adult movement is vital to understanding dynamics of coastal populations, and for effectively managing coastal fish populations within Fiordland and other subdivided systems.

Acknowledgements. We thank P. Meredith, C. Cornelisen, K. Clark, E. Emmanuelli, R. McLeod, E. Zydervelt and M. Enright for valuable field assistance and R. Frew, R. Van Hale and K. Neal at Iso-trace for providing stable isotope analyses. Additional support was provided from the University of Otago Departments of Marine Science and Chemistry, an Otago Postgraduate Award to K.L.R. and from a Marsden grant to S.R.W. (UOO213).

\section{LITERATURE CITED}

Beentjes M, Carbines G (2005) Population structure and relative abundance of blue cod (Parapercis colias) off Banks Peninsula and in Dusky Sound, New Zealand. NZ J Mar Freshw Res 39:77-90

Bligh EG, Dyer WJ (1959) A rapid method of total lipid extraction and purification. Can J Biochem Physiol 37:911-917

Boyle M, Jillett J, Mladenov P (2001) Intertidal communities in Doubtful Sound, New Zealand: changes over time. NZ J Mar Freshw Res 35:663-673

Carbines G (1999) Large hooks reduce catch-and-release mortality of blue cod Parapercis colias in the Marlborough Sounds of New Zealand. N Am J Fish Manag 
19:992-998

Carbines G, McKenzie J (2004) Movement patterns and stock mixing of blue cod in Dusky Sound in 2002. Ministry of Fisheries, Wellington

Clark K (2005) Physical factors influencing macroalgal community structure and productivity in Doubtful Sound, Fiordland. MSc thesis, University of Otago, Dunedin

Cole R, Villouta E, Davidson R (2000) Direct evidence of limited dispersal of the reef fish Parapercis colias (Pinguipedidae) within a marine reserve and adjacent fished areas. Aquat Conserv: Mar Freshwat Ecosyst 10:421-436

Cornelisen C, Wing S, Clark K, Bowman M, Frew R, Hurd C (2007) Patterns of macroalgal stable carbon and nitrogen isotope signatures: interaction between physical gradients and nutrient source pools. Limnol Oceanogr 52: 820-832

DeNiro M, Epstein S (1978) Influence of diet on the distribution of carbon isotopes in animals. Geochim Cosmochim Acta 42:495-506

DeNiro M, Epstein S (1981) Influence of diet on the distribution of nitrogen isotopes in animals. Geochim Cosmochim Acta 45:341-351

Dufour V, Pierre C, Rancher J (1998) Stable isotopes in fish otoliths discriminate between lagoonal and oceanic residents of Taiaro Atoll (Tuamotu Archipeligo, French Polynesia). Coral Reefs 17:23-28

Fry B (1981) Natural stable carbon isotope tag traces Texas shrimp migrations. Fish Bull (Wash DC) 79:337-345

Fry B (1983) Fish and shrimp migrations in the northern Gulf of Mexico analyzed using stable $\mathrm{C}, \mathrm{N}$ and $\mathrm{S}$ isotope ratios. Fish Bull (Wash DC) 81:789-801

Fry B (2006) Stable isotope ecology. Springer, New York

Fry B, Baltz D, Benfield M, Fleeger J, Gace A, Hass H, Quinones-Rivera Z (2003) Stable isotope indicators of movement and residency for brown shrimp (Farfantepenaeus aztecus) in coastal Lousiana marshscapes. Estuaries 26:82-97

Goebel N, Wing S, Boyd P (2005) A mechanism for onset of diatom blooms in a fjord with persistent salinity stratification. Estuar Coast Shelf Sci 64:546-560

Guelinckx J, Maes J, Van den Driessche P, Geysen B, DeHairs $\mathrm{F}$, Ollevier $\mathrm{F}$ (2007) Changes in $\delta^{13} \mathrm{C}$ and $\delta^{15} \mathrm{~N}$ in different tissues of juvenile sand goby Pomatoschistus minutus: a laboratory diet switch experiment. Mar Ecol Prog Ser 341: 205-215

Hansson S, Hobbie J, Elmgren R, Larsson U, Fry B, Johansson $\mathrm{S}$ (1997) The stable nitrogen isotope ratio as a marker of food web interaction and fish migration. Ecology 78: 2249-2257

Herzka S (2005) Assessing connectivity of estuarine fishes based on stable isotope ratio analysis. Estuar Coast Shelf Sci 64:58-69

Hixon M, Pacala S, Sandin S (2002) Population regulation: historical context and contemporary challenges of open vs. closed systems. Ecology 83:1490-1508

Hobson K (1999) Tracing origins and migration of wildlife using stable isotopes: a review. Oecologia 120:314-326

Jiang W, Carbines G (2002) Diet of blue cod Paraperrcis colias living on undisturbed biogenic reefs and on seabed modified by oyster dredging in Foveaux Strait, New Zealand. Aquat Conserv: Mar Freshwat Ecosyst 12:257-272

Kritzer J, Sale P (2006) Marine metapopulations. Elsevier Academic Press, London

Kurle C, Worthy G (2002) Stable nitrogen and carbon isotope ratios in multiple tissues of the northern fur seal Callorhinus ursinus: implications for dietary and migratory reconstructions. Mar Ecol Prog Ser 236:289-300
Lusseau S, Wing S (2006) Importance of pelagic subsidies versus local production to the diet of a closed population of bottlenose dolphins Tursiops sp. Mar Ecol Prog Ser 321: 283-293

Mace J, Johnson A (1983) Tagging experiments of blue cod (Parapercis colias) in the Marborough Sounds, New Zealand. NZ J Mar Freshw Res 17:207-211

McCutchan Jr, Lewis W, Kendall C, McGrath C (2003) Variation in trophic shift for stable isotope ratios of carbon, nitrogen and sulfur. Oikos 102:378-390

McLeod RJ, Wing SR (2007) Hagfish in the New Zealand fjords are supported by chemoautotrophy of forest carbon. Ecology 88:809-816

> Melville AJ, Connolly RM (2003) Spatial analysis of stable isotope data to determine primary sources of nutrition for fish. Oecologia 136:499-507

Miller S, Wing S, Hurd C (2006) Photoacclimation of Ecklonia radiata (Laminariales, Heterokontophyta) in Doubtful Sound, Fiordland. Phycologia 45:44-52

Orensanz J, Jamieson G (1998) The assessment and management of spatially structured stocks: and overview of the North Pacific Symposium on Invertebrate Stock Assessment and Management. In: Jamieson G, Campbell A (eds) Proceedings of the North Pacific Symposium on Invertebrate Stock Assessment and Management, Vol 125. Canadian Journal of Fisheries and Aquatic Science, Ottawa, p 441-459

Ostrow D, Wing S, Mladenov P, Roy M (2001) Genetic differentiation of Terebratella sanguinea in the New Zealand fjords: a dispersal barrier in the marine environment? In: Howard C, Brunton C, Robin L, Cocks M, Long S (eds) Brachiopods past and present. The Natural History Museum, London, p 150-159

Palumbi S (2003) Population genetics, demographic connectivity and the design of marine reserves. Ecol Appl 13: $146-158$

Perrin C, Roy M, Wing S (2003) Genetic differentiation amongst populations of the sea urchin Evechinus chloroticus and the sea star Coscinasterias muricata in New Zealand's fjords. In: Féral J, David B (eds) Echinoderm research 2001. Balkema, Rotterdam, p 7-13

Perrin C, Wing S, Roy M (2004) Population genetic structure amongst populations of the sea star Coscinasterias muricata in the New Zealand fjords. Mol Ecol 13:2183-2195

Peterson B (1999) Stable isotopes as tracers of organic matter input and transfer in benthic food webs, a review. Acta Oecologia 20:479-487

> Pinnegar J, Polunin N (1999) Differential fractionation of $\delta^{13} \mathrm{C}$ and $\delta^{15} \mathrm{~N}$ among fish tissues: implications for the study of trophic interactions. Funct Ecol 13:225-231

Pulliam H (1988) Sources, sinks and population regulation. Am Nat 132:652-661

Quinn J, Wing S, Botsford L (1993) Harvest refugia in marine invertebrate fisheries: models and applications to the red sea urchin Strongylocentrotus franciscanus. Am Zool 33: $537-550$

> Rau G, Mearns A, Young D, Olson R, Schafer HA, Kaplan I (1983) Animal ${ }^{13} \mathrm{C} /{ }^{12} \mathrm{C}$ correlates with trophic level in pelagic food webs. Ecology 64:1314-1318

Roughgarden J, Iwasa Y, Baxter C (1985) Demographic theory for an open marine population with space-limited recruitment. Ecology 66:54-67

Rubenstein DR, Hobson KA (2004) From birds to butterflies: animal movement patterns and stable isotopes. Trends Ecol Evol 19:256-263

$>$ Rutger S, Wing S (2006) Effects of freshwater input on shallow water infaunal communities in Doubtful Sound, New 
Zealand. Mar Ecol Prog Ser 314:35-47

Sköld M, Wing S, Mladenov P (2003) Genetic subdivision of the sea star Coscinasterias muricata in the fjords of New Zealand. Mar Ecol Prog Ser 250:163-174

Thorrold SR, Latkoczy C, Swart PK, Jones CM (2001) Natal homing in a marine fish metapopulation. Science 291: 297-299

Tieszen L, Boutton T, Tesdahl K, Slade N (1983) Fractionation and turnover of stable carbon isotopes in animal tissues: implications for $\delta^{13} \mathrm{C}$ analysis of diet. Oecologia $57: 32-37$

Wing S, Lamare M, Vasques J (2001) Population structure of sea urchins (Evechinus chloroticus) along gradients

Editorial responsibility: Otto Kinne,

Oldendorf/Luhe, Germany in primary productivity in the New Zealand fjords. In: Barker M (ed) Echinoderms. Balkema, Dunedin, p 569-575

Wing S, Gibbs M, Lamare M (2003) Reproductive sources and sinks within a sea urchin Evechinus chloroticus population of a New Zealand fjord. Mar Ecol Prog Ser 248:109-123

Wing S, Leichter J, Perrin C, Rutger S, Bowman M, Cornelisen C (2007) Topographic shading and wave exposure influence morphology and ecophysiology of Ecklonia radiata (C. Agardh 1817) in Fiordland, New Zealand. Limnol Oceanogr 52:1853-1864

Witman J, Grange K (1998) Links between rain, salinity and predation in a rocky subtidal community. Ecology 79: 2429-2447

Submitted: October 30, 2006; Accepted: November 21, 2007 Proofs received from author(s): April 15, 2008 